\title{
BRAF Gene Mutation Negative
}

National Cancer Institute

\section{Source}

National Cancer Institute. BRAF Gene Mutation Negative. NCI Thesaurus. Code C148089.

A genetic finding indicating that BRAF gene mutations have not been detected in a sample. 